\title{
Use of Educational Technologies Among Staff Members At the Faculty of Agriculture, Assiut University, Egypt
}

\author{
Bahgat M. Abdel-Maksoud \\ Agricultural Extension, Faculty of Agriculture, Assiut University, Egypt \\ E-mail:maksoud43@aun.edu.eg \\ Received on: 6/11/2016 Accepted for publication on: 15/11/2016
}

\begin{abstract}
The main objectives of this study are to know: (a) the use of educational technologies by staff members at the faculty of agriculture, Assiut University, Egypt, (2) their evaluation of the degree of importance and their level of knowledge of these technologies, and (3) reasons for not using these educational technologies. In order to achieve these objectives, an empirical inquiry was conducted to collect necessary data on the availability and use of different educational technologies among staff members at the faculty of agriculture, Assiut University. A survey was carried out on staff members holding $\mathrm{Ph}$. D. degree of this faculty. Questionnaires were distributed among staff members of the faculty. The number of usable completed returns was 100 or $39 \%$ of the total number of staff members which was estimated to be 257 members at the time of data collection (2014). Frequencies, percentages were used for data presentation. The technique of Factor analysis was applied to measure objectivity among staff members in their evaluation of the degree of importance of educational technologies in their teaching.

Results of this study showed that most respondents placed a high degree of importance of educational technologies included in this study and made use of most of these technologies. However, there are some reasons which prevent staff members from using such technologies. Some staff members lack knowledge and skills for the application of some educational technologies. A training programme should be organized for staff members at the Faculty of Agriculture, Assiut University to improve their knowledge and skills of the use of these educational technologies.
\end{abstract}

Keywords: Availability of Educational technology, Barriers to use Educational technology, Evaluation of Educational technology, Objectivity/Subjectivity Index.

\section{Introduction:}

The Association for Educational Communication and Technology's (AECT) definition of educational technology given by Januszewski \& Molenda (2008) "is the study and ethical practice of facilitating learning and improving performance by creating, using and managing appropriate technological processes and resources". Educational technology is a systematic and organized process of applying modern technology to improve the quality of education (Stosic, 2015). As defined by Aziz (2010), educational technology is the implementation of appropriate tools, techniques, or processes that facilitate the application of senses, memory, and cognition to enhance teaching practices and improve learning outcomes. It has a multi-faceted nature 
comprising a cyclical process, an arsenal of tools, and a multiple-node relationship between learners and facilitators of instruction, as well as between learners themselves (Aziz, 2010). It involves the identification, mastery and application of selected tools and techniques to promote effective teaching and enhance learning (Stryker, 2011). Educational technology is a systematic way of an application of the scientific knowledge, to improve the efficiency of the process of learning and instruction (Anand, 2011).

There are several advantages of using technology in education. Technology unlocks educational boundaries. It simplifies access to educational resource, motivates students and improve their writing and learning skills. It makes subjects easy to learn, and promotes individual learning. It supports differential instructions, and increases collaboration between teachers and students. Finally, it prepares students for tomorrows technological jobs, and increases students innovation and creativity (Ramey, 2012).

Anand (2011) points out that use of technology in education increases the effectiveness of the educational process. He states that technology is used to aid in visual representation in the classroom. Projectors, smart technologies, interactive white boards, and PCs are types of educational technologies which can be used for education. He also emphasizes the importance of training teachers on using these technologies, and the importance of using these technologies by all teachers and in all classes and not to be limited in few classes.
In spite of the above advantages, there are several barriers to the effective use of technology in education. Among these are (Ramey, 2012):

1. Lack of professional development due to the lack of training programs to teach teachers on using technology in education and the lack of technological tools available for teachers.

2. Teachers' resistance to change is another barrier which may be due to lack of technical training, lack of technologies, the long time needed for learning these technologies, or fear of using them.

3. Lack of innovation. As pointed out by Ramey (2012 that using technological tools requires a certain degree of creativity since they are designed to do more than one task.

4. Lack of access to technological tools such as lack of enough computers and access to internet.

Educational technology has passed through five stages. The first is the use of audio-visual aids. The second stage is associated with the electronic revolution. The third stage is inked with the development of mass media which in turn led to communication revolution for instructional purposes. The fourth stage of educational technology is the invention of self learning based on self instructional materials. The latest is the development of multi-media technologies and the use of the computer in instruction (Deka, 2014).

Types of educational technology:

There are various types of educational technologies which can be used as teaching tools and as learning 
tools. They can be used also in formal education, non-formal education, and informal education. Each of these technologies has its strengths and weaknesses. They should be combined to see to see their true potential. These technologies can be grouped under three main categories (Anand, 2011):

1. Visual technology which includes:

(a) Projectors: Video Projectors, Slide Projectors, Overhead Projectors, Opaque Projector, Book

(b)Book Projector + Book Reader, LCD / DLP Projectors

(c) SMART Technologies

(SMART boards)

(d)Classroom PCs

2. Computer technology through the application of various programmes which help educators in presentation and students practice skills and review material such as Word processing and Power point.

3. Internet technology which can provide resource and websites for practicing skills and monitoring student progress.

\section{Objectives:}

The main objectives of this study are to:

1. Identify types of educational technologies available for staff members at the faculty of agriculture, Assiut University, Egypt.

2. Examine staff members' use of these educational technologies in their teaching.

3. Examine staff members' evaluation of the degree of importance of Information Communication Technology (ICT).

4. Measure the degree of objectivity among staff members in their evaluation of the degree of importance of these ICT.

5. Examine staff members' evaluation of their level of knowledge of these ICT.

6 . Investigate reasons for not using these educational technologies among staff members at the faculty of Agriculture, Assiut University, Egypt.

\section{Methodology:}

In order to achieve the objectives of this study, an empirical inquiry was undertaken to collect necessary data on the availability and use of different educational technologies among staff members at the faculty of agriculture, Assiut University, Egypt. Individual interviews with some officials at this faculty were undertaken to identify the available educational technologies in class rooms of the faculty. To examine staff members' use of the identified technologies and their evaluation of the degree of importance of ICT technologies and their level of knowledge of them, a survey was carried out on staff members holding Ph.D. of this faculty. Questionnaires were distributed among staff members of the faculty. The number of usable completed returns was 100 or $39 \%$ of the total number of staff members which was estimated to be 257 members at the time of data collection (2014). Frequencies, percentages were used for data presentation. The technique of Factor analysis was applied to measure objectivity among staff members in their evaluation of the degree of importance of ICT in their teaching.

\section{Results:}


Results of this study can be summarized as follows:

\section{A. Respondents' characteristics:}

Results show that over two thirds of respondents were 50 years or more. Most of them (65\%) were professors. The majority of them had ten years or more of experience, and had been abroad for one to 15 years for studying or work, visited one or more of foreign countries, and had been exposed to one or more training courses on ICT (Table 1).

Table 1. Distribution of respondents according to their characteristics

\begin{tabular}{|c|c|c|}
\hline Characteristics & Number & $\%$ \\
\hline \multicolumn{3}{|l|}{ 1. Age: } \\
\hline $30-39$ & 14 & 15.1 \\
\hline $40-49$ & 16 & 17.2 \\
\hline $50-59$ & 24 & 25.8 \\
\hline $60-69$ & 26 & 28.0 \\
\hline $70-79$ & 13 & 14.0 \\
\hline Total & 93 & 100.0 \\
\hline \multicolumn{3}{|l|}{ 2. Occupational degree: } \\
\hline Lecturer & 24 & 25.5 \\
\hline Assistant professor & 9 & 9.6 \\
\hline Professor & 23 & 24.5 \\
\hline Professor emirate & 38 & 40.4 \\
\hline Total & 94 & 100.0 \\
\hline \multicolumn{3}{|l|}{ 3. Years of experience: } \\
\hline Less than 10 years & 29 & 30.8 \\
\hline $10-19$ years & 13 & 13.8 \\
\hline $20-29$ years & 23 & 24.5 \\
\hline 30 years or more & 29 & 30.9 \\
\hline Total & 94 & 100.0 \\
\hline \multicolumn{3}{|l|}{ 4. Years of working abroad: } \\
\hline None & 25 & 26.6 \\
\hline $1-4$ years & 39 & 41.5 \\
\hline $5-9$ years & 26 & 27.7 \\
\hline $10-15$ years & 4 & 4.3 \\
\hline Total & 94 & 100.0 \\
\hline \multicolumn{3}{|l|}{ 5. Number of foreign countries visited: } \\
\hline None & 26 & 27.7 \\
\hline One & 41 & 43.6 \\
\hline Two or more & 27 & 28.7 \\
\hline Total & 94 & 100.0 \\
\hline \multicolumn{3}{|l|}{ 6. Number of training courses attended: } \\
\hline None & 39 & 40.6 \\
\hline One & 23 & 24.0 \\
\hline Two or more & 34 & 35.4 \\
\hline Total & 96 & 100.0 \\
\hline
\end{tabular}

Source: Questionnaire forms 
B. Availability and use of educational technologies:

A variety of educational technologies are available at the faculty. Fourteen types of these technologies were determined to be included in this study. These include the blackboard, the whiteboard, the interaction board, the microphone, use of computer and data show projectors for word document and power point presentation, use of data show projectors to present pages from a book, photos, graphs, maps, and video films. They also include using the in- ternet, some statistical programs, a pointer, a remote control to change slides, and face book and twitter. Results showed that most of these technologies were used (always or sometimes) by most respondents. Only four of the included technologies were rarely or not used by most respondents. These are: the interactive board, using data show to present pages from a book, using data show to present word documents, and using data show to present power point slides (Table 2).

Table 2. Distribution of respondents according to their use of educational technologies (Percentages)

\begin{tabular}{|l|c|c|c|c|c|}
\hline Technology & $\begin{array}{c}\text { Total } \\
\text { Number }\end{array}$ & $\begin{array}{c}\text { Don't } \\
\text { use }\end{array}$ & $\begin{array}{c}\text { Rarely } \\
\text { use }\end{array}$ & $\begin{array}{c}\text { Sometimes } \\
\text { use }\end{array}$ & $\begin{array}{c}\text { Always } \\
\text { use }\end{array}$ \\
\hline 1. Blackboard & 98 & 31.6 & 14.3 & 39.8 & 14.3 \\
\hline 2. Whiteboard & 100 & 11 & 7 & 46 & 36 \\
\hline 3. Interaction board & 100 & 76 & 8 & 12 & 4 \\
\hline 4. Microphone & 100 & 17 & 13 & 35 & 35 \\
\hline 5. Word document & 100 & 50 & 8 & 22 & 20 \\
\hline 6. Power point & 100 & 7 & & 19 & 74 \\
\hline 7. Pages from a book & 100 & 46 & 15 & 25 & 14 \\
\hline 8. Photos, graphs, maps & 99 & 25.3 & 3 & 32.3 & 39.4 \\
\hline 9. Video films & 100 & 37 & 2 & 43 & 18 \\
\hline 10. Pages from the internet & 100 & 33 & 4 & 40 & 23 \\
\hline 11. Statistical programs & 100 & 43 & 11 & 25 & 21 \\
\hline 12. Pointer & 100 & 33 & 5 & 34 & 28 \\
\hline 13. Remote control to change slides & 100 & 30 & 9 & 31 & 30 \\
\hline 14. Face book, twitter & 100 & 31 & 12 & 40 & 17 \\
\hline Source: Computed from
\end{tabular}

Source: Computed from data collected

\section{Respondents' evaluation of} the degree of importance of ICT technologies:

Respondents were asked to evaluate the degree of importance of eight technologies. These are: the use of computer, internet, e-mail, word document, power point, excel, making sites on the internet, and face book. All these technologies were evaluated as important and very important by most respondents (Table $3)$. 
Table 3. Distribution of respondents according to their evaluation of the degree of importance of educational technologies (Percentages)

\begin{tabular}{|l|c|c|c|c|c|c|}
\hline \multirow{2}{*}{\multicolumn{1}{|c|}{ Technology }} & \multicolumn{7}{c|}{ Degree of importance } \\
\cline { 2 - 7 } & $\begin{array}{c}\text { Total } \\
\text { Number }\end{array}$ & $\begin{array}{c}\text { Very } \\
\text { High }\end{array}$ & High & Medium & Low & $\begin{array}{c}\text { Very } \\
\text { Low }\end{array}$ \\
\hline 1. Use of computer & 96 & 88.5 & 11.5 & & & \\
\hline 2. Internet & 95 & 80.0 & 18.9 & 1.1 & & \\
\hline 3. Email & 94 & 68.1 & 23.4 & 7.4 & & 1.1 \\
\hline 4. Word document & 87 & 74.7 & 19.5 & 4.6 & 1.1 & \\
\hline 5. Power point & 94 & 75.5 & 18.1 & 5.3 & 1.1 & \\
\hline 6. Excel & 82 & 42.7 & 35.4 & 20.7 & & 1.2 \\
\hline 7. Making sites on the Internet & 90 & 23.3 & 38.9 & 30.0 & 5.6 & 2.2 \\
\hline 8. Face book, twitter & 94 & 17.0 & 36.2 & 30.9 & 8.5 & 7.4 \\
\hline
\end{tabular}

Source: Computed from data collected

D. Objectivity among respondent in their evaluation of the degree of importance of ICT:

Objectivity/subjectivity among respondents in their evaluations of the degree of importance of ICT can be measured by different methods. Among these methods is the application of factor analysis (Guilford, 1954). Through this method, values of communalities of respondents are obtained and can be regarded as in- dex of objectivity among individuals. Factor analysis was applied to measure objectivity among respondents and the values of communalities obtained for respondents are given in Table 4. Only one value was 0.884 , and all other values ranged from 0.931 to 1.00 . This is an indication that a high degree of objectivity existed among respondents in their evaluations of the degree of importance of ICT in their teaching.

Table 4. Results of the application of Factor Analysis

(Values of Communalities of Respondent)*

\begin{tabular}{|c|c|c|c|c|c|c|c|c|}
\hline .996 & .931 & .986 & 1.000 & .997 & .996 & .997 & 1.000 & .969 \\
\hline .990 & 1.000 & 1.000 & .997 & 1.000 & .967 & .884 & 1.000 & 1.000 \\
\hline 1.000 & .997 & 1.000 & .999 & .999 & .989 & 1.000 & 1.000 & 1.000 \\
\hline .996 & .997 & .992 & 1.000 & 1.000 & 1.000 & 1.000 & .996 & 1.000 \\
\hline .999 & 1.000 & .995 & 1.000 & .999 & .998 & .996 & .970 & \\
\hline .999 & .997 & .999 & .997 & .996 & .983 & .989 & .996 & \\
\hline 1.000 & .998 & 1.000 & 1.000 & 1.000 & .999 & .999 & .997 & \\
\hline
\end{tabular}

Source: Computed from data collected

*A number of cases was omitted to apply Factor Analysis.

E. Respondents' evaluation of their level of knowledge of ICT:

The majority of respondents evaluated their level of knowledge as high and very high for five technolo- gies. Respondents' level of knowledge was evaluated as medium, low, and very low for using excel, making sites on the internet, and face book (Table 5). 
Table 5. Distribution of respondents according to their evaluation of their level of knowledge of educational technologies (Percentages)

\begin{tabular}{|l|c|c|c|c|c|c|}
\hline \multirow{2}{*}{\multicolumn{1}{|c|}{ Technology }} & \multicolumn{6}{c|}{ Level of knowledge } \\
\cline { 2 - 7 } & $\begin{array}{c}\text { Total } \\
\text { Number }\end{array}$ & $\begin{array}{c}\text { Very } \\
\text { High }\end{array}$ & High & Medium & Low & $\begin{array}{c}\text { Very } \\
\text { Low }\end{array}$ \\
\hline 1. Use of computer & 82 & 31.7 & 39.0 & 26.8 & 2.4 & \\
\hline 2. Internet & 81 & 38.3 & 35.8 & 23.5 & 2.5 & \\
\hline 3. Email & 81 & 45.7 & 29.6 & 18.5 & 4.9 & 1.2 \\
\hline 4. Word document & 73 & 47.9 & 24.7 & 24.7 & 2.7 & \\
\hline 5. Power point & 81 & 43.2 & 33.3 & 14.8 & 8.6 & \\
\hline 6. Excel & 69 & 26.1 & 18.8 & 40.6 & 13.0 & 1.4 \\
\hline 7. Making sites on the Internet & 71 & 4.2 & 12.7 & 46.5 & 25.4 & 11.3 \\
\hline 8. Face book, and twitter & 74 & 17.6 & 20.3 & 41.9 & 10.8 & 9.5 \\
\hline
\end{tabular}

Source: Computed from data collected

F. Reasons for using/not using educational technologies:

Respondents were asked to state reasons for using and not using each of the educational technologies included. The most frequent mentioned reasons for using educational technologies were: for explanation and demonstration, to facilitate presentation, and to exchange scientific material with students. The most frequent mentioned reasons for not using these technologies were: no need for the technology, and non-availability of it (Table 6).
Respondents were also asked to state reasons preventing them from using educational technologies. Mentioned. The most frequent reasons mentioned by respondents were: preferring conversation and discussion with students, preferring talking to give examples, preferring using or accustomed to use traditional methods, fear of breakdown of equipment, and no-availability of equipment (Table 7). 
Table 6. Reasons for using/not using educational technology

\begin{tabular}{|c|c|c|c|c|}
\hline \multirow[b]{2}{*}{$\begin{array}{l}\text { Educational } \\
\text { technology }\end{array}$} & \multicolumn{2}{|l|}{ Reasons for using } & \multicolumn{2}{|c|}{ Reasons for not using } \\
\hline & Reason & $\begin{array}{c}\text { No. of } \\
\text { mentions }\end{array}$ & Reason & $\begin{array}{l}\text { No. of men- } \\
\text { tions }\end{array}$ \\
\hline $\begin{array}{l}\text { Use of data show to } \\
\text { present Word docu- } \\
\text { ment }\end{array}$ & $\begin{array}{l}\text { (1) For explanation and demonstration } \\
\text { (2) Presenting more material } \\
\text { (3) increase effectiveness of other meth- } \\
\text { ods } \\
\text { (4) More appropriate for subject } \\
\text { (5) Presentation of Tables } \\
\text { (6) A useful mean }\end{array}$ & $\begin{array}{l}5 \\
2 \\
2 \\
1 \\
1 \\
1\end{array}$ & $\begin{array}{l}\text { (1) No need for it } \\
\text { (2) Prefer Power Point } \\
\text { (3) Frequent breakdown } \\
\text { (4) Prefer traditional means }\end{array}$ & $\begin{array}{l}3 \\
3 \\
1 \\
1\end{array}$ \\
\hline $\begin{array}{l}\text { Use of data show to } \\
\text { present Power Point } \\
\text { slides }\end{array}$ & $\begin{array}{l}\text { (1) For explanation and demonstration } \\
\text { (2) Attractive } \\
\text { (3) More effective } \\
\text { (4) More appropriate for subject } \\
\text { (5) Presentation of Tables } \\
\text { (6) Save time } \\
\text { (7) increase effectiveness of other meth- } \\
\text { ods }\end{array}$ & $\begin{array}{l}14 \\
2\end{array}$ & $\begin{array}{l}\text { (1) No need for it } \\
\text { (2) Frequent breakdown } \\
\text { (3) Non-availability }\end{array}$ & $\begin{array}{l}1 \\
1 \\
1\end{array}$ \\
\hline $\begin{array}{l}\text { Use of data show to } \\
\text { present Pages from a } \\
\text { book }\end{array}$ & $\begin{array}{l}\text { (1) For explanation and demonstration } \\
\text { (2) Correct some errors } \\
\text { (3) Presentation of important pages } \\
\text { (4) increase effectiveness of other meth- } \\
\text { ods }\end{array}$ & $\begin{array}{l}6 \\
1 \\
1 \\
1\end{array}$ & $\begin{array}{l}\text { (1) No need for it } \\
\text { (2) Frequent breakdown } \\
\text { (3) Not appropriate }\end{array}$ & $\begin{array}{l}2 \\
1 \\
1\end{array}$ \\
\hline $\begin{array}{l}\text { Use of data show to } \\
\text { present Photo, shapes, } \\
\text { and diagrams }\end{array}$ & $\begin{array}{l}\text { (1) For explanation and demonstration } \\
\text { (2) Attractive } \\
\text { (3) More effective } \\
\text { (4) More appropriate for subject } \\
\text { (5) Increase effectiveness } \\
\text { of other methods } \\
\end{array}$ & $\begin{array}{l}8 \\
1 \\
1 \\
1\end{array}$ & $\begin{array}{l}\text { (1) No need for it } \\
\text { (2) Frequent breakdown }\end{array}$ & $\begin{array}{l}1 \\
1\end{array}$ \\
\hline $\begin{array}{l}\text { Use of data show to } \\
\text { present Video films }\end{array}$ & $\begin{array}{l}\text { (1) For explanation and demonstration } \\
\text { (2) Available at the Internet } \\
\text { (3) Increase effectiveness of other meth- } \\
\text { ods } \\
\text { (4) More appropriate for subject }\end{array}$ & $\begin{array}{l}9 \\
1 \\
1 \\
1\end{array}$ & $\begin{array}{l}\text { (1) No need for it } \\
\text { (2) Non-availability }\end{array}$ & $\begin{array}{l}4 \\
4\end{array}$ \\
\hline $\begin{array}{l}\text { Use of data show to } \\
\text { present Pages from the } \\
\text { internet }\end{array}$ & $\begin{array}{l}\text { (1) For explanation and demonstration } \\
\text { (2) Train students } \\
\text { (3) Available at the Internet } \\
\text { (4) Increase effectiveness of other meth- } \\
\text { ods } \\
\text { (5) Modern information }\end{array}$ & $\begin{array}{l}7 \\
2 \\
1 \\
1 \\
1\end{array}$ & $\begin{array}{l}\text { (1) No need for it } \\
\text { (2) Non-availability }\end{array}$ & $\begin{array}{l}3 \\
1\end{array}$ \\
\hline Use of some programs & $\begin{array}{l}\text { (1) For statistical analysis in research } \\
\text { (2) Explanation of certain processes } \\
\text { (3) Increase effectiveness of other meth- } \\
\text { ods }\end{array}$ & $\begin{array}{l}8 \\
2 \\
1\end{array}$ & (1) No need for it & 3 \\
\hline Use of Pointer & $\begin{array}{l}\text { (1) Focusing on certain issues } \\
\text { (2) Increase effectiveness of other meth- } \\
\text { ods } \\
\text { (3) Free movement }\end{array}$ & $\begin{array}{c}11 \\
1 \\
1\end{array}$ & $\begin{array}{l}\text { (1) Non-availability } \\
\text { (2) Non-concentration }\end{array}$ & $\begin{array}{l}3 \\
1\end{array}$ \\
\hline Use of Remote control & $\begin{array}{l}\text { (1) Facilitate presentation } \\
\text { (2) Free movement } \\
\text { (3) control presentation }\end{array}$ & $\begin{array}{l}5 \\
2 \\
1 \\
\end{array}$ & $\begin{array}{l}\text { (1) Non-availability } \\
\text { (2) Frequent breakdown }\end{array}$ & $\begin{array}{l}9 \\
1\end{array}$ \\
\hline $\begin{array}{l}\text { Use of E-mail, Face } \\
\text { book, and Twitter }\end{array}$ & $\begin{array}{l}\text { (1) Exchange scientific material with stu- } \\
\quad \text { dents } \\
\text { (2) Activation of communication process } \\
\text { (3) Fast } \\
\text { (4) More effective } \\
\text { (5) Not expensive } \\
\text { (6) Important mean } \\
\text { (7) Increase knowledge }\end{array}$ & $\begin{array}{l} \\
3 \\
3 \\
2 \\
1 \\
1 \\
1 \\
1\end{array}$ & $\begin{array}{l}\text { (1) Non-availability } \\
\text { (2) Misuse of it } \\
\text { (3) students' unwillingness }\end{array}$ & $\begin{array}{l}2 \\
2 \\
1\end{array}$ \\
\hline
\end{tabular}

Source: Questionnaire forms 
Table 7. Reasons preventing respondents from using ICT

\begin{tabular}{|l|c|}
\hline \multicolumn{1}{|c|}{ Reasons } & Number of mentions \\
\hline 1. Prefer conversation and discussion with students & 22 \\
\hline 2. Prefer talking to give examples & 18 \\
\hline 3. Prefer using blackboard & 17 \\
\hline 4. Accustomed to use traditional methods & 8 \\
\hline 5. Fear of breakdown of equipment & 6 \\
\hline 6. No-availability of equipment & 6 \\
\hline 7. No need for it & 4 \\
\hline 8. Not interested in knowing it & 4 \\
\hline
\end{tabular}

Source: Questionnaire forms

\section{Conclusion:}

Based on the results of this study, it can be concluded that most staff members at the Faculty of Agriculture at Assiut University placed a high degree of importance of educational technologies included in this study and made use of most of these technologies. However, there are some reasons which prevent staff members from using such technologies. Some staff members lack knowledge and skills for the application of some educational technologies such the interactive board, using data show to present pages from a book, using data show to present word documents and power point slides, use of excel, making site on the internet, and use of social media (face book and twitter). A training programme should be organized for staff members at the Faculty of Agriculture, Assiut University to improve their knowledge and skills of the use of these educational technologies.

\section{References:}

Anand, K. (2011). Educational Technology and Its Application in Formal and Non-formal Education. Educational and Instructional Technology Assignment. Pondicherry Uni- versity. India. Available at: http://www.slideshare.net/Anandka b/educational-technology-and-itsapplication-by-anand

Aziz, H. (2010). The 5 Keys to Educational Technology. Availble at:https://thejournal.com/articles/2 010/09/16/the-5-keys-toeducational-technology.aspx

Deka, Sanjoy (2014). History of Educational Technology. Ezine Article. Available At: http://EzineArticles.com/expert=Sa njoy_Deka

Guilford, J. P. (1954). Psychometric Methods, McGraw-Hill Book Company, New York,

Toronto, London, Second Edition.

Januszewski, A., \& Molenda, M. (2008). Chapter 1: Definition. In Januszewski, A., \& Molenda, M. (Eds.), Educational technology: A definition with commentary. New York: Lawrence Erlbaum Associates.

Nie, Norman H.; Hadlaihull, C.; Jenkins, J. G.; Steinbrenner, K. and Bent, D. H. (1975). SPSS Statistical Package for the Social Sciences, Second Edition, McGraw-Hill Book Company, New York. 
Ramey, K. (2012). The Use of Technology - In Education and Teaching Process. Use of Technology, Available At: http://www.useoftechnology.com/t he-use-of-technology-in-education/ Stosic, Lazar (2015). The Importance of Educational Technology in Teaching. International Journal of Cognitive Research in Science, Engineering and Education. Vol. 3, No.
1., Available At:

http://www.ijcrsee.com/index.php/ ijcrsee/article/view/166/316

Stryker, Chris, (2011). The Educational Technology at the United Arab Emirates University. Journal of Educational Technology and Learning, Vol. 2, August. 
إستخدام تكنولوجيا التعليم بين أعضاء هيئة التدريس بكلية الزراعة - جامعة أسيوط

بهجت محمد عبد المقصود

قسم الإرشاد الزر اعى - كلية الزراعة - جامعة أسيوط

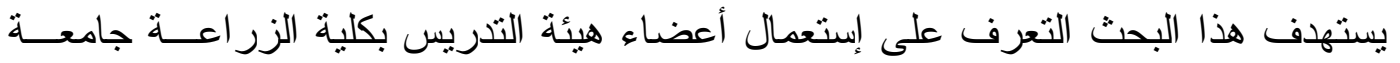

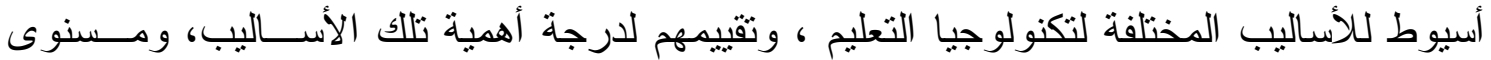

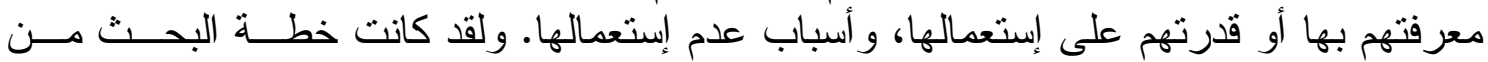

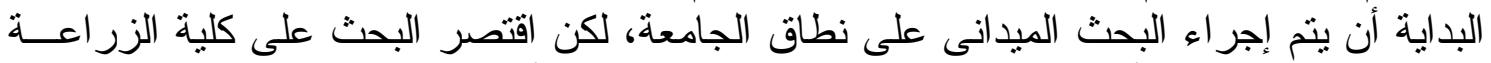

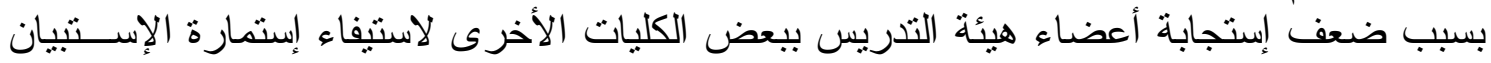

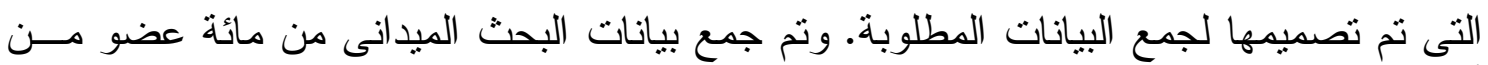

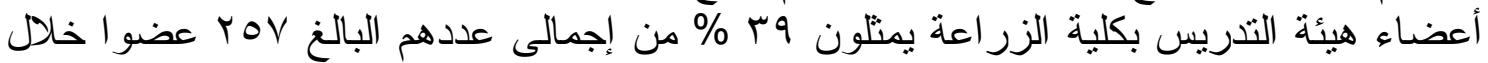

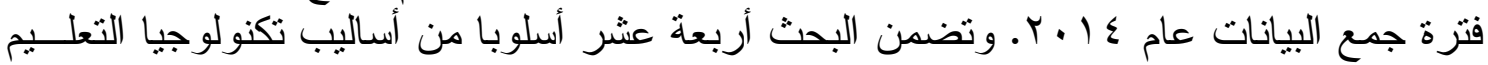

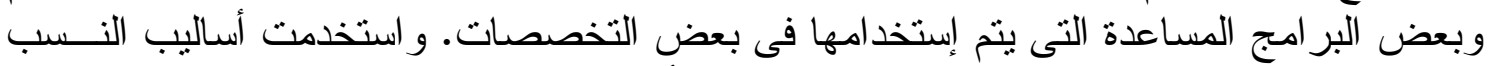

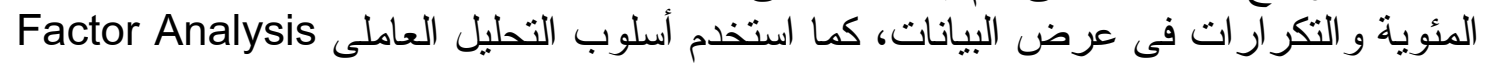

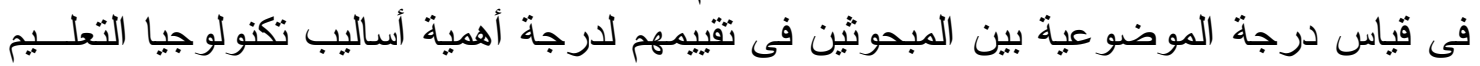
التى تضمنها هذا البحث.

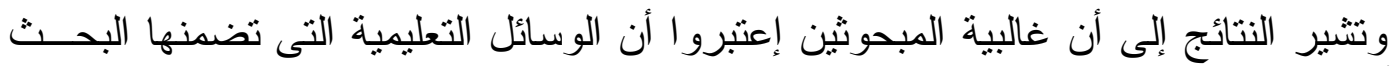

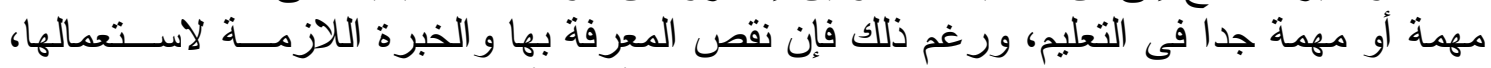

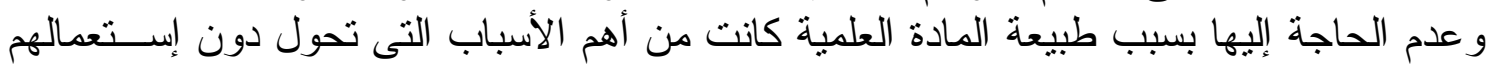
ويوصى البحث بضرورة تتظيم التدريب المناسب لتعميم إستعمال أساليب تكتولوجيا التعليم

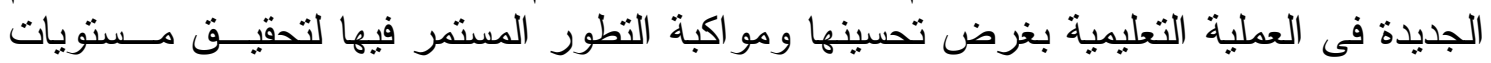
جودة التعليم المنشودة. 